\title{
Андрей АСТВАЦАТУРОВ
}

\section{«ТРАНСАТЛАНТИКА» В СМОЛЬНОМ: ЛИТЕРАТУРНЫЕ СВЯЗИ НОВОГО И СТАРОГО СВЕТА}

UDC 82(091)

DOI https://doi.org/10.22455/2541-7894-2020-8-489-490

\section{Andrey ASTVATSATUROV \\ TRANSATLANTICA AT SMOLNY: OLD WORLD-NEW WORLD LITERARY CONTACTS}

The review traces reports and discussions of the International conference Transatlantic Relations in American and European Literature hosted at the Saint Petersburg State University on June 19-20, 2019. The conference aimed to bring together research scholars to exchange and share their experiences and research results on the dynamic processes and cultural transfer in the Northern Atlantic region. The papers focused on the Anglo-American Modernism with its principal centers in London, New York and Paris and on numerous periodicals which created intercultural dialogue in 1910-1930s. The participants also turned to other periods of the literary history and highlighted various aspects of the image and ideology reception on both sides of the Atlantic Ocean. The conference gathered scholars from Moscow, Saint Petersburg, Kazan, Rostov-on-Don - specialists in American literary history (T. Venediktova, O. Panova, A. Astvatsaturov, M. Oshukov, Ya. Probshtein, O. Antsyferova, O. Nesmelova, O. Karasik, O. Polovinkina, A. Kalashnikov, K. Vikhrova, M. Arshinov) and in Slavic studies (E. Penskaya, D. Ioffe, V. Feshchenko, O. Sokolova, A. Rosliy, E. Pavlov). The program of the conference also included presentations on history of English (O. Dzhumailo), German (I. Lagutina), Spanish (N. Kharitonova), French (L. Muravyeva), Greek (P. Zarutskiy), Finnish (V. Verzunova) literatures, literary theory (A. BazhenovaSorokina, A. Shvets), history of philosophy (D. Khaustov) and cinema (L. Bugaeva). The speakers considered different trajectories of the transatlantic transfer (US-Europe, USGreat Britain, US-Russia / USSR), outlined various methodological problems relevant to its description, gave interpretations of the real encounters, discussed possible encounters and even paradoxical "non-encounters". The conference became a unique example of a productive dialogue between scholars - representatives of different generations and academic schools.

(C) 2020 Андрей Алексеевич Аствацатуров (кандидат филол. наук, доцент; Санкт-Петербургский государственный университет) astvatsa@yandex.ru

(C) 2020 Andrey A. Astvatsaturov (PhD, Associate Professor; Saint Petersburg State University) astvatsa@yandex.ru 
19-20 июня 2019 г. в Санкт-Петербургском государственном университете состоялась международная научная конференция «Трансатлантические связи в американской и европейской литературе». Организационный комитет (А.А. Аствацатуров, В.В. Фещенко, О.В. Соколова, Т.Д. Венедиктова, О.Ю. Панова, Е.В. Павлов, Д.Г. Иоффе) ставил перед собой задачу объединить усилия специалистов в области англоязычных и европейских литератур и обсудить трансатлантические рейды и связи литераторов по обе стороны Атлантики. В центре внимания был, разумеется, англо-американский модернизм 1910-1930-х гг. с тремя его центрами - Лондон, Нью-Йорк, Париж и многочисленными периодическими изданиями, осуществлявшими диалог культур, вроде знаменитого журнала transition, издававшегося Ю. Джоласом.

Этот период был, в самом деле, беспрецедентным в плане интенсивности диалога и совместной работы литераторов разных стран и континентов. Ни до, ни после ничего подобного в культуре не происходило: феномен «трансатлантического» англо-американского модернизма вызревал достаточно долго, а после мощного всплеска 1910-х-1930-х гг. контакты продолжались, хотя и в несколько ослабленной форме. И все же организаторы решились расширить круг обсуждаемых проблем и включить в повестку конференции вопросы, касающиеся контактов, которые происходили в другие периоды литературной истории, а также уделить внимание различным аспектам рецепции образов или идеологий по обе стороны Атлантики.

Конференция объединила несколько поколений современных филологов, а также представителей разных региональных школ (Москва, Санкт-Петербург, Казань, Ростов-на-Дону) и разных профилей. Среди докладчиков преобладали американисты (Т. Венедиктова, О. Панова, А. Аствацатуров, М. Ошуков, Я. Пробштейн, О. Анцыферова, О. Несмелова, О. Карасик, О. Половинкина, А. Калашников, К. Вихрова, М. Аршинов) и слависты (Е. Пенская, Д. Иоффе, В. Фещенко, О. Соколова, А. Рослый, Е. Павлов). Кроме того, на конференции выступали исследователи истории европейских литератур - английской (О. Джумайло), немецкой (И. Лагутина), испанской (Н. Харитонова), французской (Л. Муравьева), греческой (П. Заруцкий) и финской (В. Верзунова), специалисты в области теории литературы (А. Баженова-Сорокина, А. Швец), истории философии (Д. Хаустов) и кино (Л. Бугаева). Участники обсудили различные траектории трансатлантического трансфера (США - Европа, США - Великобритания, США - Россия / СССР), которые осуществлялись на протяжении XIX и XX вв., очертили зоны рецепции, обозначили ряд методологических проблем, возникающих при их описании, проанализировали реальные встречи, обсудили возможные встречи и даже парадоксальные «невстречи». Доклады сопровождались дискуссиями, иногда острыми, но, в целом, диалог исследователей, принадлежащих к разным поколениям и разным научным школам, можно считать вполне состоявшимся. 